Reckless

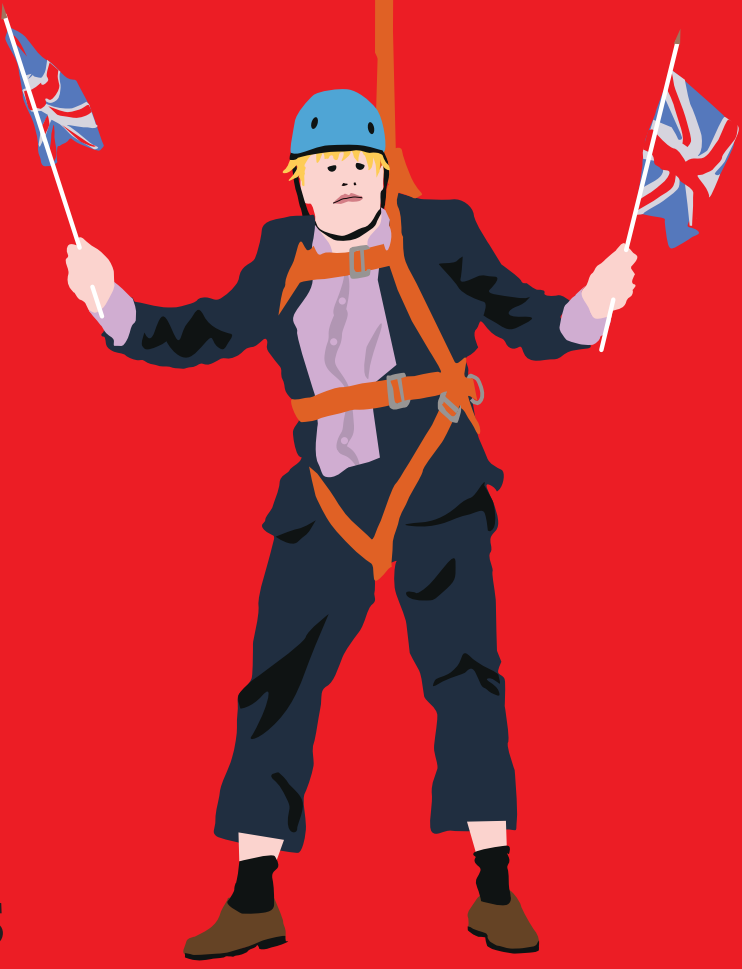

opportunists

Elites at the end

of the Establishment

Aeron Davis 


\section{Reckless opportunists}

\section{MANCHESTER 1824}

Manchester University Press 


\section{The Manchester Capitalism book series}

\section{General Editor}

\section{MICK MORAN}

Manchester Capitalism is a series of books which follows the trail of money and power across the systems of our failing capitalism. The books make powerful interventions about who gets what and why in a research-based and solidly argued way that is accessible for the concerned citizen. They go beyond critique of neoliberalism and its satellite knowledges to re-frame our problems and offer solutions about what is to be done.

Manchester was the city of Engels and Free Trade where the twin philosophies of collectivism and free market liberalism were elaborated. It is now the home of this venture in radical thinking that challenges self-serving elites. We see the provincial radicalism rooted here as the ideal place from which to cast a cold light on the big issues of economic renewal, financial reform and political mobilisation.

Already published:

The end of the experiment?: From competition to the foundational economy

Licensed larceny: Infrastructure, financial extraction and the global South

What a Waste: Outsourcing and how it goes wrong

The econocracy: The perils of leaving economics to the experts

Forthcoming:

Safe as houses: Private greed, political negligence and housing policy after Grenfell

Foundational economy: The infrastructure of everyday life

Systems city: A new politics of provision for an urbanized planet

Our academic editors are Julie Froud and Mick Moran. Our commissioning editors at MUP are Tom Dark and Tony Mason. 


\section{Praise for Reckless opportunists}

'Aeron Davis has spent two decades talking to members of the financial, political, and media elites - and here he lines them all up to explain how they've created the debacle that is Brexit Britain. The company boss says he may himself be sacked at any moment. The prize-winning journalist worries over why he hasn't got the story everyone else apparently has. And the law-maker admits he hasn't a clue about the laws he's passing. And the only thing stopping them carrying on like this forever is bad luck - or a better democracy.' Aditya Chakrabortty, Senior Economics Commentator, The Guardian

'Aeron Davis pulls back the curtain on the wizards of $\mathrm{Oz}$ who rule us. And having studied them for decades he tells their story brilliantly. They were never as good as we were led to believe. Leadership doesn't have to be solitary, rich, nasty, brutish and short. It can be connected, modestly-paid, nice, civilized and long. And that would be pretty beneficial to everyone else too.'

Danny Dorling, Professor of Geography at the University of Oxford

'An indispensable addition to elite scholarship that was decades in the making and arrives not a minute too soon. As the West continues to quake in the face of "populist" furore, Aeron Davis's deft analysis of his "barbarians inside the gate" shows an establishment torn asunder. Confounding past assumptions of both the left and right, Davis weaves the reader through the top corridors of U.K. power, and finds an elite that is "precarious, rootless and increasingly self-serving." Scholars and pundits trying to make sense of the establishment overthrow in the West will ignore Reckless opportunists at their own peril.'

Janine. R. Wedel, author of Unaccountable: How the Establishment Corrupted Our Finances, Freedom, and Politics and Created an Outsider Class and University Professor in the Schar School of Policy and Government, George Mason University

'Aeron Davis's new book on the Establishment re-writes the rules of the genre. He is a rare thing, a critical outsider who has managed to gain extensive insider access. His close-up accounts offer fascinating new insights into the apparent dysfunction of modern politics and sometimes the dysfunctionality of modern day politicians.' Iain Dale, political commentator, publisher, LBC broadcaster

'Chaos often feels like the best word to describe the world my generation is inheriting. Reckless opportunists shines a light on how the decay of the Establishment feeds that chaos. It's terrifying but it also gives me hope that a different and better world is possible.' Joe Earle, co-author of The econocracy 
Aeron Davis - 9781526158680

Downloaded from manchesterhive.com at $04 / 26 / 2023$ 01:32:28PM 


\section{Reckless opportunists}

\section{Elites at the end of the Establishment}

Aeron Davis

Manchester University Press 
Copyright (C) Aeron Davis 2018

The right of Aeron Davis to be identified as the author of this work has been asserted by him in accordance with the Copyright, Designs and Patents Act 1988.

Published by Manchester University Press

Altrincham Street, Manchester M1 7JA

www.manchesteruniversitypress.co.uk

British Library Cataloguing-in-Publication Data

A catalogue record for this book is available from the British Library

ISBN 9781526127273 hardback

ISBN 9781526127280 paperback

First published 2018

The publisher has no responsibility for the persistence or accuracy of URLs for any external or third-party internet websites referred to in this book, and does not guarantee that any content on such websites is, or will remain, accurate or appropriate.

Typeset

by Toppan Best-set Premedia Limited 